\title{
Nutritional value of some feedstuffs used in the diet of captive capybaras
}

\author{
Djalma Nóbrega Ferreira1', Alcester Mendes', Sérgio Luiz Gama Nogueira-Filho ${ }^{1,2}$
}

\author{
${ }^{1}$ Laboratório de Nutrição de Animais Silvestres, Universidade Estadual de Santa Cruz. \\ ${ }^{2}$ Departamento de Ciências Agrárias e Ambientais, Universidade Estadual de Santa Cruz, Rod. Ilhéus-Itabuna Km 16, Ilhéus, Bahia, Brazil, \\ 45662-900.
}

\begin{abstract}
Five pen-raised adult female capybaras were used in five digestibility trials in a Latin square design, to determine, for capybaras, the nutritional values of Cameroon grass (Pennisetum purpureum cv. Cameroon); Napier grass (P. purpureum cv. Napier); corn grain; cassava hay, comprising leaves and stems; and palm kernel (Elaeis guineensis) cake. These feedstuffs were provided separately or mixed, in a completely randomized manner, in different experimental periods. The digestibility of each feedstuff not supplied alone was estimated by difference. The animals were individually introduced in metabolism pens. Following a 10-day period of adaptation to each diet, feed intake was recorded and total fecal output was collected over five consecutive days. Energy, crude protein and neutral detergent fiber digestibilities of Cameroon grass were, respectively, $0.88( \pm 0.07$, standard deviation), $0.63( \pm 0.39)$ and $0.82( \pm 0.15)$. For Napier grass they were $0.84( \pm 0.05), 0.63$ $( \pm 0.12)$ and $0.72( \pm 0.10)$; for corn grain, $0.92( \pm 0.05), 0.97( \pm 0.20)$ and $0.83( \pm 0.14)$; for cassava hay, $0.86( \pm 0.12), 0.84( \pm 0.14)$ and $0.43( \pm 0.16)$; and for palm kernel cake $0.94( \pm 0.05), 0.85( \pm 0.14)$, and $0.97( \pm 0.05)$. These digestibilities in capybaras were higher than the digestibilities of the same feedstuffs in other livestock. These results can be explained by the anatomical and physiological characteristics of the capybara, which lead to a high rate of nutrient digestion and absorption.
\end{abstract}

Key Words: by-product feedstuffs, capybara nutrition, digestibility of nutrients, wildlife farming

\section{Introduction}

Capybaras (Hydrochoerus hydrochaeris) breed relatively easily in captivity (Ojasti, 1991); this trait, in association with other biological and behavioral characteristics -sedentarism, docility, and sociability - has encouraged the captive breeding of capybaras in Latin American countries (Ojasti, 1991; González-Jiménez, 1995; Nogueira-Filho \& Nogueira, 2004; Alvarez \& Kravetz, 2006). However, the main factor that has favored the domestication of the capybara is its diet (Emmons, 1987). Capybaras consume mainly grass (Ojasti, 1973; Alho et al., 1987), producing meat and leather (Frasson \& Salgado 1990; González-Jiménez, 1995).

This herbivore species has a simple stomach and can digest roughage due to mastication followed by microbial fermentation in the cecum (González-Jiménez \& Escobar, 1975). Much of its diet in captivity is therefore appropriately comprised of grass (Emmons, 1987; Nogueira-Filho \& Nogueira, 2004). However, tropical grasses are low in both energy and protein (Pond et al., 2004). Growth and reproduction require higher levels of protein and energy than maintenance alone. Because of this, some concentrate feedstuffs with higher energy and protein content than grass should also be provided for capybaras that are growing and reproducing (Mendes \& Nogueira-Filho, 2012). Moreover, previous studies suggest that the fiber content becomes more digestible after energy and protein supplements have been added to the diet (González-Jiménez \& Escobar, 1975; Bernardi, 1993).

To formulate diets appropriately, it is imperative to know the nutritional value of the feedstuffs to be used for the species in question. Nevertheless, there is no information to date on the nutritional value of feedstuffs for this species. Therefore, the objective of this study was to assess the nutritional values of some feedstuffs for capybaras.

\section{Material and Methods}

The protocol of this experiment was approved by the Animal Care and Use Committee (CEUA) of Universidade Estadual de Santa Cruz, and was carried out in accordance with the Guide for the Care and Use of Laboratory Animals (NRC, 1996).

To determine the coefficient of total tract apparent digestibility (CTTAD) of the tested feedstuffs, five adult female capybaras between two and four years of age and weighing $29.0 \pm 4.1$ (standard deviation) $\mathrm{kg}$ were 
individually placed in pens that were built for metabolism trials. At this time, they were weighed and dewormed with febendazole (Panacur ${ }^{\circledR}$ Intervet/Schering-Plough Animal Health, $5 \mathrm{mg} \mathrm{kg}^{-1}$ of live weight). These procedures took place one month before the start of the study on CTTAD determination, which enabled animals to adapt to the experimental conditions. Each pen measured $11.3 \mathrm{~m}^{2}(7.5 \mathrm{~m}$ length $\times 1.5 \mathrm{~m}$ breadth), and was partially sheltered $\left(9 \mathrm{~m}^{2}\right)$ with $2.3 \mathrm{~m}^{2}$ of solarium. The concrete floor was surrounded by a wire mesh fence of $1.5 \mathrm{~m}$ in height. Each pen had a feeder $(1.10 \mathrm{~m}$ long $\times 0.25 \mathrm{~m}$ wide $\times 0.15 \mathrm{~m}$ high $)$ and a water trough $(0.20 \mathrm{~m}$ in diameter $\times 0.15 \mathrm{~m}$ height $)$. The wire mesh fence was used between pens to allow visual, auditory, and olfactory contact between neighbors in an attempt to reduce the stress caused by the isolation of these highly social animals. Moreover, the pens were built in a similar way to those described by Mendes et al. (2000), which allowed capybaras to follow their customary cecotrophic behavior.

To determine the CTTAD of dry matter (DM), organic matter (OM), crude protein (CP) and gross energy (GE) for capybaras, the following feedstuffs were provided in a completely randomized design in different experimental periods: Cameroon grass (Pennisetum purpureum cv. Cameroon); Napier grass (P. purpureum cv. Napier); corn grain; cassava hay, comprising leaves and stems; and palm kernel (Elaeis guineensis) cake. These feedstuffs were provided separately or mixed, determining the experimental diets (Tables 1 and 2). The CTTAD of the feedstuffs not supplied alone was estimated by difference, using the method described by Coelho da Silva \& Leão (1979), which minimizes the negative associative effects on fiber digestion induced by starch. Thus, to determine the digestibility coefficients by difference in the nutrients of corn grain, Cameroon grass was considered the basal diet. For both cassava hay and palm kernel cake, Cameroon grass and corn grain were considered components of the basal diet.

Following a 10-day period of adaptation to each diet, feed intake was recorded and total fecal output was collected over five consecutive days. All capybaras were weighed 24 hours before they started to eat each new diet and 24 hours after the last day that they received the same diet. Data on changes in body weight, expressed as daily weight gain $\left(\mathrm{g} \mathrm{day}^{-1}\right)$, were obtained by dividing the difference between the final and the initial live weight by the 15 days of each trial. Until the 7th day of the adaptation period, the feed was available ad libitum; three days prior to the fecal collection period, and during the collection periods, the feed was provided at about 0.9 of the minimum

Table 1 - Overview of all diets to determine the coefficient of total tract apparent digestibility of each ingredient for capybara and method of evaluation

\begin{tabular}{|c|c|c|c|}
\hline Ingredients to be evaluated & Method of evaluation & Experimental diets & Amount supplied (daily) \\
\hline Cameroon grass & Direct & Diet A & Cameroon grass $^{1}(1500 \mathrm{~g})$ and mineral salt $\mathrm{mix}^{2}$ \\
\hline Napier grass & Direct & Diet B & Napier $\operatorname{grass}^{3}(1600 \mathrm{~g})$ and mineral salt $\mathrm{mix}^{2}$ \\
\hline Cassava hay ${ }^{5}$ & Substitution $^{4}$ & Diet D & $\begin{array}{l}\text { Cameroon grass }{ }^{1}(1300 \mathrm{~g}) \text {, corn grain }(200 \mathrm{~g}) \text { cassava leaf hay } \\
(100 \mathrm{~g}) \text {, and mineral salt } \mathrm{mix}^{2}\end{array}$ \\
\hline
\end{tabular}

${ }^{1}$ The elephant grass cv. Cameroon was used in all diets (excepted as noted). This grass was cut at 60 days of age and chopped prior to feeding.

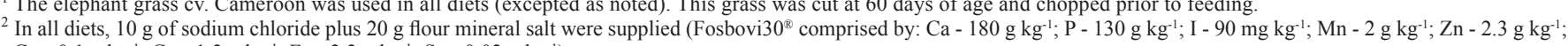
$\left.\mathrm{Co}-0.1 \mathrm{~g} \mathrm{~kg}^{-1} ; \mathrm{Cu}-1.2 \mathrm{~g} \mathrm{~kg}^{-1} ; \mathrm{Fe}-2.2 \mathrm{~g} \mathrm{~kg}^{-1} ; \mathrm{Se}-0.02 \mathrm{~g} \mathrm{~kg}^{-1}\right)$.

${ }^{3}$ Elephant grass cv. Napier, cut at 60 days of age and chopped prior to feeding.

${ }^{4}$ Substitution of a basal diet (difference).

${ }^{5}$ Cassava hay comprising leaves and stems.

Table 2 - Chemical composition ( $\mathrm{g} \mathrm{kg}^{-1} \mathrm{DM}$ excepted as noted) of the feedstuffs used in the experimental diets

\begin{tabular}{lccccc}
\hline & Cameroon grass & Napier grass & Corn grain & Cassava hay $^{1}$ & Palm kernel cake \\
\hline Dry matter & 207 & 200 & 848 & 858 & 926 \\
Organic matter & 799 & 870 & 831 & 97 & 163 \\
Crude protein & 58 & 62 & 99 & 384 & 157 \\
Neutral detergent fiber & 721 & 740 & 40 & 646 \\
Acid detergent fiber & 415 & 459 & 17.6 & 386 \\
Gross energy (MJ kg-1 DM) & 16.7 & 15.9 & & 18.8 & 19.7 \\
\hline
\end{tabular}

${ }^{1}$ Cassava hay comprising leaves and stems. 
intake observed during the adaptation period, to avoid refusal of feed and the possible effect on CTTAD. Water was available ad libitum and $30 \mathrm{~g}$ of powdered mineral salt mix was supplied daily (Table 1).

The same person fed the animals with fresh feed once a day at $6.00 \mathrm{pm}$. Two people were on duty in shifts 24 hours a day and caught the feces as soon as they were produced, using a scoop shovel. The collected feces were immediately weighed and stored at $-20{ }^{\circ} \mathrm{C}$ in identified plastic bags for later analyses. These procedures prevented both the contamination of feces by urine and the need to keep capybaras in metabolism crates, which would have led the animal to present abnormal behavior (Bernardi, 1993).

The dry matter, organic matter, crude protein and gross energy contents were determined following the methodologies described by Nogueira \& Souza (2005). Before analyses, feeds and feces were dried at $60{ }^{\circ} \mathrm{C}$ for 72 hours and ground to pass through a $1 \mathrm{~mm}$ screen for analyses. Dry matter (DM) was determined by drying in an oven at $105{ }^{\circ} \mathrm{C}$ for 16 hours. Ash was determined by ignition in a muffle furnace at $550{ }^{\circ} \mathrm{C}$ for 4 hours. Crude protein $(\mathrm{CP})$ was measured as kjeldahl $\mathrm{N} \times 6.25$. The gross energy (GE) of diet and feces was determined by bomb calorimeter using a Parr adiabatic calorimeter. The neutral detergent fiber (NDF) and acid detergent fiber (ADF) analyses were conducted following the procedure of Van Soest et al. (1991) and Van Soest (1973).

Correlation matrix was employed using NDF and ADF contents of the feedstuffs as independent variables and CTTAD of DM, OM, CP, GE, and NDF as dependent variables. The daily weight gains for each experimental diet were compared by repeated ANOVA measures, followed by post hoc Tukey HSD tests. All analyses used $<0.05$ significance level and the same statistical package was used for every data analysis (Statistica version 7.0 - StatSoft, Tulsa, OK, USA).

\section{Results and Discussion}

The CTTAD of dry matter ranged from 0.58 to 0.88 , while the CTTAD of crude protein ranged from 0.63 to 0.97 (Table 3). These values were higher than those previously recorded for capybaras (Table 4). The differences can be explained by the experimental conditions adopted. In the previous studies, capybaras were maintained in metabolism crates (González-Jiménez \& Escobar, 1975; Bernardi, 1993), while in the present one, they were maintained in relatively large pens, as recommended by Mendes et al. (2000). Thus,

Table 3 - Mean ( \pm standart error) coefficients of total tract apparent digestibility of feedstuffs for capybaras

\begin{tabular}{|c|c|c|c|c|c|}
\hline & Cameroon grass & Napier grass & Corn grain & Cassava hay ${ }^{1}$ & Palm kernel cake \\
\hline Dry matter & $0.60(0.15)$ & $0.58(0.13)$ & $0.88(0.09)$ & $0.72(0.41)$ & $0.86(0.14)$ \\
\hline Organic matter & $0.60(0.17)$ & $0.60(0.13)$ & $0.98(0.14)$ & $0.82(0.29)$ & $0.86(0.15)$ \\
\hline Crude protein & $0.63(0.39)$ & $0.63(0.12)$ & $0.97(0.20)$ & $0.84(0.14)$ & $0.85(0.14)$ \\
\hline Neutral detergent fiber & $0.82(0.15)$ & $0.72(0.10)$ & $0.83(0.14)$ & $0.43(0.16)$ & $0.97(0.05)$ \\
\hline Gross energy & $0.88(0.07)$ & $0.84(0.05)$ & $0.92(0.05)$ & $0.86(0.12)$ & $0.94(0.05)$ \\
\hline
\end{tabular}

${ }^{1}$ Cassava hay comprising leaves and stems.

Table 4 - Comparative CTTAD of dry matter, crude protein, neutral detergent fiber, and gross energy between capybaras, rabbits, crossbred steers (Bos tourus $\times$ B. indicus) and buffalos

\begin{tabular}{|c|c|c|c|c|c|}
\hline & Dry matter & Crude protein & Neutral detergent fiber & Gross energy & Authors \\
\hline \multicolumn{6}{|c|}{ Capybaras } \\
\hline Grass/concentrate $^{1}$ & 0.60 & 0.68 & 0.49 & 0.62 & Bernardi (1993) \\
\hline Grass/concentrate $^{1}$ & 0.64 & & & & González-Jiménez \& Escobar (1975) \\
\hline \multicolumn{6}{|c|}{ Rabbits (Oryctolagus cuniculus) } \\
\hline Napier grass & 0.46 & 0.65 & 0.42 & 0.45 & Cheeke (1987) \\
\hline Corn grain & - & 0.85 & - & 0.87 & Scapinello et al. (1995) \\
\hline Cassava hay $^{2}$ & - & 0.52 & - & 0.49 & Herrera (2003) \\
\hline Palm kernel cake & - & 0.54 & 0.43 & 0.55 & Carrión et al. (2011) \\
\hline \multicolumn{6}{|c|}{ Crossbred steers $($ Bos taurus $\times B$. indicus $)$} \\
\hline Napier grass & 0.57 & 0.58 & 0.58 & 0.59 & Ribeiro et al. (2008) \\
\hline Cassava hay $^{2}$ & 0.52 & 0.40 & 0.35 & - & Euclides et al. (1979) \\
\hline \multicolumn{6}{|c|}{ Buffalos (Bubalus bubalis) } \\
\hline Napier grass & 0.56 & 0.64 & 0.52 & 0.56 & Grant et al. (1974) \\
\hline
\end{tabular}

${ }^{1}$ Grass and concentrate diet: proportion of $0.6: 0.4$, on a dry matter basis.

${ }^{2}$ Cassava hay comprising leaves and stems.

CTTAD - coefficients of total tract apparent digestibility 
in the present study, the pens were large enough to allow total freedom of movement, so capybaras could practice cecotrophy - as fortuitously observed by the researchers - which explains the higher dry matter digestibility coefficients obtained in comparison with the previous studies.

Cecotrophy is the habit of producing and eating distinctive soft feces (Sakaguchi, 2003). Capybaras produce two distinctly different kinds of feces, an amorphous type called cecotroph, formed by cecal contents and ingested, which contains more crude protein and less fiber than the normal oval feces (Mendes et al., 2000). Cecotrophy has been observed both in wild and captive capybaras (Herrera, 1985; Borges et al., 1996; Mendes et al., 2000). Through cecotrophy, the digesta is recycled, allowing certain feeds that were not digested the first time to be broken down, improving the use of nutrients and energy in the diet (Cheeke, 1987). This ensures greater protein absorption in the diet and digestion of microbial protein produced in the cecum in cecotrophic animals (Sakaguchi, 2003).

In this study, as in the previous ones (GonzálezJiménez \& Escobar, 1975; Bernardi, 1993), capybaras digested dietary fiber components (Table 3) as effectively as sheep. Besides, the CTTAD of dry matter, crude protein, neutral detergent fiber and gross energy in the present study were higher than the CTTAD of the same feedstuffs in rabbits, crossbred steers (Bos tourus $\times$ B. indicus) and buffaloes (Bubalus bubalis) (Table 4). The large cecum of capybaras has a digestive capacity similar to that of the rumen of sheep (Parra \& González-Jiménez, 1971), which results in similar mean retention time of digesta in the gastrointestinal tract between these species on similar diets (González-Jiménez et al., 1976).

Digesta retention is a major determinant of fiber digestibility (Clauss et al., 2009), because a long retention time of digesta in the fermentation chamber commonly causes high digestibility of the fiber component (Sakaguchi, 2003). Moreover, capybaras masticate ingested forages until they are reduced to extremely small particles (Baldizán et al., 1983), which results in greater relative surface area exposed to microbial attack (Pond et al., 1984). Both characteristics lead to a high rate of fiber digestion and digestible energy intake. Despite that, the fiber contents of the feedstuffs affected the CTTAD of dry matter, organic matter, crude protein and gross energy of the feedstuffs provided (Table 5), as occurs in domestic and wild ruminants (van Soest, 1994).

The intake of both digestible energy and digestible protein (DP) was above the maintenance levels required for capybaras of $274 \mathrm{~kJ} \mathrm{~kg}^{-0.75}$ and $2.5 \mathrm{~g} \mathrm{DP} \mathrm{kg}^{-0.75}$, respectively, (Ojasti, 1973; González-Jiménez \& Escobar, 1975) for all diets supplied. The results explained why capybaras showed a positive, albeit different $(\mathrm{P}=0.0001)$, daily weight gain when fed these diets (Figure 1).

Table 5 - Correlation matrix between the CTTAD of dry matter, organic matter, crude protein, gross energy, and neutral detergent fiber for capybara and the fiber contents (NDF and ADF) of the feedstuffs supplied

\begin{tabular}{lcccc}
\hline CTTAD & NDF rPearson & P & ADF rPearson & P \\
\hline Dry matter & -0.57 & 0.04 & -0.56 & 0.03 \\
Organic matter & -0.56 & 0.04 & -0.59 & 0.04 \\
Crude protein & -0.66 & 0.001 & -0.69 & 0.009 \\
Gross energy & -0.74 & 0.004 & -0.77 & 0.002 \\
\hline
\end{tabular}

CTTAD - coefficients of total tract apparent digestibility; NDF - neutral detergent fiber; ADF - acid detergent fiber.

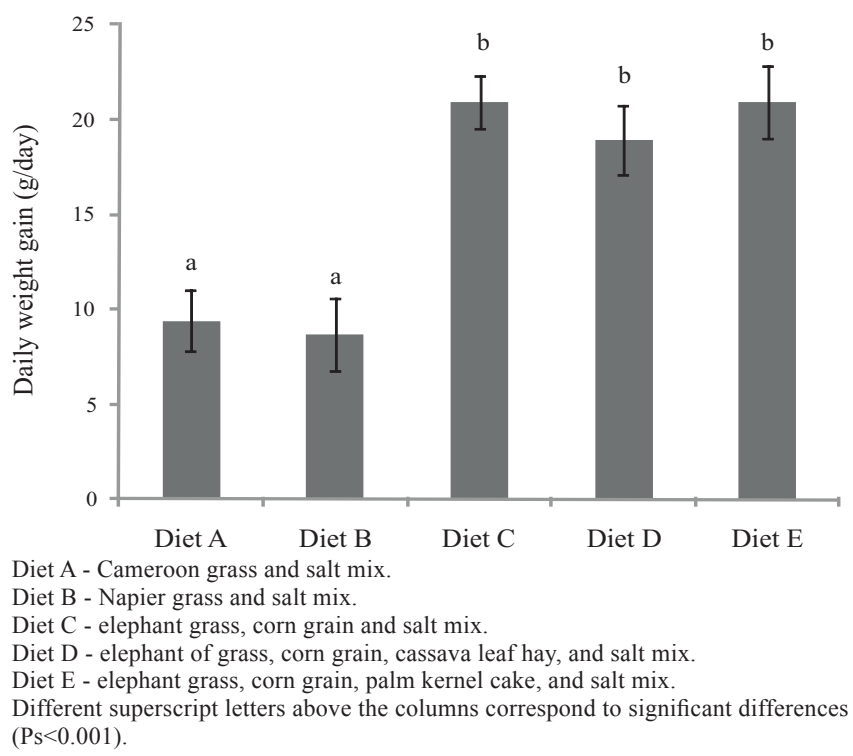

Figure 1 - Mean daily weight gain (g/day) of capybaras in the eight experimental diets.

\section{Conclusions}

Energy, crude protein and neutral detergent fiber digestibilities of Cameroon grass were, respectively, 0.88 ( \pm 0.07 , standard deviation), $0.63( \pm 0.39)$ and $0.82( \pm 0.15)$; for Napier grass, $0.84( \pm 0.05), 0.63( \pm 0.12)$ and $0.72( \pm 0.10)$; for corn grain, $0.92( \pm 0.05), 0.97( \pm 0.20)$ and $0.83( \pm 0.14)$; $0.86( \pm 0.12), 0.84( \pm 0.14)$ and $0.43( \pm 0.16)$ for cassava hay; and $0.94( \pm 0.05), 0.85( \pm 0.14)$ and $0.97( \pm 0.05)$ for palm kernel cake. These digestibilities in capybaras were higher than the digestibilities of the same feedstuffs in other livestock. These results can be explained by the anatomical and physiological characteristics of the capybara, which lead to a high rate of nutrient digestion and absorption. 


\section{Acknowledgements}

The authors are grateful to Dr. José Augusto Gomes de Azevedo and to the anonymous Associate Editor, for the valuable comments on this manuscript; to Conselho Nacional de Pesquisa e Desenvolvimento Científico e Tecnológico (CNPq), Coordenação de Aperfeiçoamento de Pessoal de Nível Superior (CAPES/PNPD) and UESC, for the financial support; and to CNPq (Proc. \# 300587/ 2009-3) and CAPES (PNPD), for the fellowships granted to authors Sérgio Luiz Gama Nogueira-Filho and Alcester Mendes, respectively.

\section{References}

ALHO, C.J.R.; CAMPOS, Z.M.S.; GONÇALVES, H.C. Ecologia de capivara (Hydrochaeris hydrochaeris, Rodentia) no Pantanal: I habitats, densidades e tamanho de grupo. Revista Brasileira de Biologia, v.47, p.87-97, 1987.

ALVAREZ, M.R.; KRAVETZ, F.O. Reproductive performance of capybaras (Hydrochoerushydrochaeris) in captivity under different management systems in Argentina. Animal Research, v.55, p.153-164, 2006.

BALDIZÁN, A.; DIXON, R.M.; PARRA, R. Digestion in the capybara (Hydrochoerus hydrochaeris). South African Journal of Animal Science, v.13, p.27-28, 1983.

BERNARDI, L.G. Efeito dos níveis crescentes de volumoso sobre a digestibilidade de nutrientes de rações para capivaras $(\mathrm{Hydr}$ ochoerushydrochaerishydrochaeris, L. 1766). 1993. 203f. Thesis (Animal Science M.Sc.) - Escola Superior de Agricultura "Luiz de Queiroz"/Universidade de São Paulo, Piracicaba, São Paulo, Brazil.

BORGES, P.A.; DOMINGUEZ-BELLO, M.G.; HERRERA, E.A. Digestive physiology of wild capybara. Journal of Comparative Physiology B, v.166, p.55-60, 1996.

CARRIÓN, S.; DE BLAS, J.C.; MÉNDEZ, J. et al. Nutritive value of palm kernel meal in diets for growing rabbits. Animal Feed Science and Technology, v.165, p.79-84, 2011.

COELHO DA SILVA, J.F.; LEÃO, M.I. Fundamentos da nutrição dos ruminantes. Piracicaba: Livroceres, 1979. 380p.

CLAUSS, M.; NUNN, C.L.; FRITZ, J. et al. Evidence for a tradeoff between retention time and chewing efficiency in large mammalian herbivores. Comparative Biochemistry and Physiology A, v.154, p.376-382, 2009.

CHEEKE, P.R. Rabbit feeding and nutrition. Oregon: Academic Press, 1987. 380p.

EMMONS, L.H. Ecological considerations on the farming of game animals: capybaras yes, pacas no. Vida Silvestre Neotropical, v.1, p.54-55, 1987.

EUCLIDES, V.P.B.; SILVA, J.M.; O'DONOVAN, P.B. Efeito da suplementação com feno da parte aérea da mandioca sobre o consumo e digestibilidade da palha de arroz. Cuiabá: Embrapa Gado de Corte, 1979. p.1-3. (Comunicado Técnico, 1).

FRASSON, C.; SALGADO, J.M. Capivara - Uma opção contra a fome e a deficiência de proteína animal. In: SIMPÓSIO INTERFACE NUTRIÇÃO X AGRICUlTURA, 2., 1990, Piracicaba. Anais... Piracicaba: FEALQ, 1990. p.175-200.

GONZÁLEZ-JIMÉNEZ, E.; ESCOBAR, A. Digestibilidad comparada entre chigüires (Hydrochoerus hydrochaeris), conejos y ovinos con raciones de diferentes proporciones de forrajes y concentrado. Agricultura Tropical, v.25, p.283-290, 1975.
GONZÁLEZ-JIMÉNEZ, E.; ESCOBAR, A.; CAIRES, O. Un metodo para detectar coprofagia - Resultados em chigüires (Hydrochoerus hydrochaeris). In: SEMINARIO SOBRE CHIGÜIRE Y BABAS, 1976, Maracay. Programa y resumenes... Maracay: Faculdad de Agronomia, CONICIT/I.P.A., 1976. p.81-82.

GONZÁLEZ JIMÉNEZ, E. El capibara (Hydrochoerus hydrochaeris). Estado actual de su producción. Roma: Estudio FAO Producción y Sanidad Animal, 1995. v.122, p.1-110.

GRANT, R.J.; VAN SOEST, P.J.; MACDOWELL, R.E. et al. Intake, digestibility and metabolic loss of napier grass by cattle and buffaloes when fed wilted, chopped and whole. Journal Animal Science, v.39, p.423-434, 1974.

HERRERA, A.P.N. Eficiência produtiva e avaliação nutricional de dietas simplificadas a base de forragens para coelhos em crescimento. 2003. 104f. Dissertation (Animal Science Ph.D.) Escola de Veterinária/Universidade Federal de Minas Gerais, Belo Horizonte, Brazil.

HERRERA, E.A. Coprophagy in capybara, Hydrochoerus hydrochoeris. Journal of Zoology, v.217, p.616-619, 1985.

MENDES, A.; NOGUEIRA, S.S.C.. NOGUEIRA-FILHO, S.L.G. et al. A note on cecotrophy behavior in capybara (Hydrochaeris hydrochaeris). Applied Animal Behaviour Science, v.66, p.161-167, 2000.

MENDES, A.; NOGUEIRA-FILHO, S.L.G. Feeds and nutrition of farmed capybaras. In: MOREIRA J.R.; FERRAZ, K.M.P.M.B.; HERRERA, E.A. et al. (Eds.) Capybara: biology, use and conservation of an exceptional neotropical species. Nova York: Springer, 2012. p.261-274.

NOGUEIRA, A.R.A.; SOUZA, G.B. Manual de laboratórios: solo, água, nutrição vegetal, nutrição animal e alimentos. 1.ed. São Carlos: Gráfica \& Editora Guillen e Andrioli, 2005. v.1, 328p.

NOGUEIRA-FILHO, S.L.G.; NOGUEIRA, S.S.C. Captive breeding program as an alternative for wildlife conservation in Brazil. In: KIRSTEN S.; FRAGOSO, J.M.V.; BODMER R. (Eds.) People in nature: wildlife management and conservation in Latin America. New York: Columbia University Press, 2004. p.171-190.

OJASTI, J. Estudio biológico del chigüire o capibara. Caracas: Fondo Nacional Investigación Agropecuária, Ed. Sucre, 1973. $275 \mathrm{p}$.

OJASTI, J. Human exploration of capybara. In: ROBINSON, J.G., REDFORD, K.H. (Eds.) Neotropical wildlife use and conservation. Chicago: University of Chicago Press, 1991. p.236-252.

PARRA, R.; GONZÁLEZ-JIMÉNEZ, E. Fisiologia digestiva del chigüire (Hydrochoerus hydrochaeris). 1. Capacidad de los diferentes compartimentos del tracto digestivo. In: Maracay: IPA, 1971. 14p. Informe al Proyecto CONICIT, DF 030-51.

POND, K.R.; ELLIS, W.C.; AKIN, D.E. Ingestive mastication and fragmentation of forages. Journal of Animal Science, v.58, p.1367-1374, 1984.

RIBEIRO, E.G.; FONTES, C.A.A.; PALIERAQUI, C.E.M. et al. Influência da irrigação durante as épocas secas e chuvosas na taxa de lotação, no consumo e no desempenho de novilhos em pastagens de capim-elefante e capim-monbaça. Revista Brasileira de Zootecnia, v.37, p.1546-1554, 2008.

SAKAGUCHI, E. Digestive strategies of small hindgut fermenters. Animal Science Journal, v.74, p.327-337, 2003.

SCAPINELLO C.; TAFURI, M.L.; ROSTAGNO, H.S. et al. Revista Brasileira de Zootecnia, v.24, p.1001-1007, 1995.

VAN SOEST, P.J. Collaborative study of acid detergent fiber and lignin. Journal Association of Official Analytical Chemists, v.56, p.781-784, 1973.

VAN SOEST, P.J.; ROBERTSON, J.B.; LEWIS, B.A. Methods for dietary fiber, neutral detergent fiber and non-starch polysaccharides in relation in animal nutrition. Journal of Dairy Science, v.74, p.3583-3597, 1991.

VAN SOEST, P.J. Nutritional ecology of the ruminant. 2.ed. Ithaca, New York: Cornell University Press, 1994. 476p. 